\title{
Monetary Policy in the United States: A Brave New World?
}

Stephen D. Williamson

This article is a reflection on monetary policy in the United States during Ben Bernanke's two terms as Chairman of the Federal Open Market Committee, from 2006 to 2014. Inflation targeting, policy during the financial crisis, and post-crisis monetary policy (forward guidance and quantitative easing) are discussed and evaluated. (JEL E52, N12)

Federal Reserve Bank of St. Louis Review, Second Quarter 2014, 96(2), pp. 111-21.

en Bernanke chaired his last Federal Open Market Committee (FOMC) meeting in January 2014 and departed from the Board of Governors on February 3 after eight years as the head of the Federal Reserve System. So, the time is right to look back on the Bernanke era and ask how central banking has and has not changed since 2006.

There is plenty in the macroeconomic record from 2006 to 2014 to keep economists and policy analysts busy for many years, so in this short piece we can only scratch the surface of what is interesting about the Bernanke era. I will focus on three issues: (i) inflation targeting, (ii) Fed lending and other interventions during the financial crisis, and (iii) post-crisis Fed policy, in particular experiments with forward guidance and quantitative easing (QE).

\section{INFLATION TARGETING}

When Bernanke began his first term in 2006, I think the big change people expected was an inflation-targeting regime for U.S. monetary policy, similar to what exists in New Zealand, Canada, and the United Kingdom, for example. While that may have been in the cards, by the time Bernanke had settled into the job, events had overtaken him and he clearly ended up with much more than he bargained for. In terms of how Fed officials think about their jobs and how the public thinks about the role of the central bank, the Fed's objectives and its toolbox are far different from what existed, or was envisioned, in 2006.

Ben Bernanke was on record prior to his time as Fed Chair as a supporter of inflation targeting (see, for example Bernanke, 2004), which, as noted, had been adopted in other central

Stephen D. Williamson is the Robert S. Brookings Distinguished Professor in Arts and Sciences at Washington University in St. Louis, a research fellow at the Federal Reserve Bank of St. Louis, and a visiting scholar at the Federal Reserve Bank of Richmond.

(c) 2014, The Federal Reserve Bank of St. Louis. The views expressed in this article are those of the author(s) and do not necessarily reflect the views of the Federal Reserve System, the Board of Governors, or the regional Federal Reserve Banks. Articles may be reprinted, reproduced, published, distributed, displayed, and transmitted in their entirety if copyright notice, author name(s), and full citation are included. Abstracts, synopses, and other derivative works may be made only with prior written permission of the Federal Reserve Bank of St. Louis. 


\section{Figure 1}

\section{PCE Deflator and 2 Percent Trend}

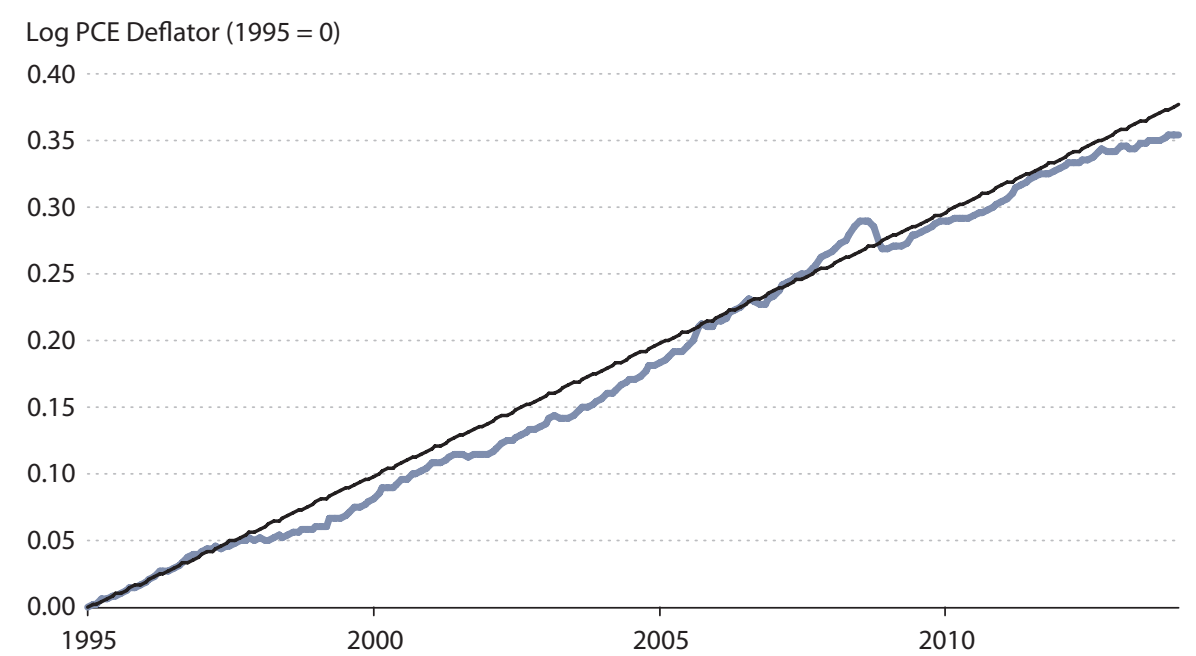

banks, including those in New Zealand, Canada, and the United Kingdom. Bernanke (2004) argued that, in spite of the Fed's successes in controlling inflation, beginning in the Volcker era, it would be an improvement if the Fed stated a specific target for the inflation rate.

While Fed communications during Bernanke's term changed in ways that reflected more explicitly the dual mandate that comes from the U.S. Congress, the Fed ultimately stated explicitly that its target was a 2 percent per year increase in the raw personal consumption expenditures (PCE) deflator. In early 2012, a set of long-run goals for monetary policy were laid out by the Fed, which included this specific inflation target (see Board of Governors, 2012). This version of inflation targeting differs from that in some other countries (e.g., New Zealand or Canada) where there is an explicit agreement between the national government and the central bank that there will be an inflation target that is periodically renegotiated. In the United States, the central bank took it upon itself to come up with the inflation-targeting approach.

Figure 1 shows the path for the PCE deflator from January 1995 to February 2014, along with a 2 percent growth trend. This is quite remarkable, as inflation has actually not strayed far from the 2 percent trend path over this 19 -year period. Thus, the Fed's announced inflationtargeting approach was simply ratifying a policy that had implicitly been in place for a long time. Thus, while announcing the 2 percent inflation target may have been important in reinforcing the Fed's commitment to low inflation, it appears that the Fed could have announced such a target in 1995 and that this would not have constrained its behavior. Perhaps surprisingly, once the Fed had announced the 2 percent inflation target, it began missing it on the low side, currently by about as much as at any time between January 1995 and the present. 


\section{THE FINANCIAL CRISIS: CENTRAL BANK LENDING, BAGEHOT'S RULE, AND MORAL HAZARD}

It will take us many years to sort out what happened during the financial crisis and why. We do not even have all the facts yet, and I am sure there will be important revelations when the principals (hopefully including Bernanke) write about it. For starters, it is useful to read the transcript from a conference at the Brookings Institution in January 2014 (see Brookings Institution, 2014). This part of the discussion, between Chairman Bernanke and Liaquat Ahamed at the conference, relates to the principles of central banking in a financial crisis:

Mr. Ahamed: You've said somewhere that the playbook that you relied on was essentially given by a British economist in the 1860s, Walter Bagehot. And his dictum was that in a financial crisis, the Central Bank should lend unlimited amounts to solvent institutions against good collateral at a penalty rate. How useful in practice was that rule in guiding you?

Mr. Bernanke: It was excellent advice. This was the advice that's been used by Central Banks going back to at least the 1700s. When you have a market or a financial system that is short of liquidity and there's a lack of confidence, a panic; then the Central Bank is the lender of last resort. It's the institution that can provide the cash liquidity to calm the panic and to make sure that depositors and other short-term lenders are able to get their money.

In the context of the crisis of 2008, the main difference was that the financial system that we have today obviously looked very different in its details, if not in its conceptual structure, from what Walter Bagehot saw in the 19th century. And so the challenge for us at the Fed was to adapt Bagehot's advice to the context of a modern financial system. So for example, instead of having retail depositors lining out, you know, standing in line out the doors as was the case in the 1907 panic, for example, in the United States; we had instead runs by wholesale short-term lenders like repo lenders or commercial-paper lenders, and we had to find ways to essentially provide liquidity to stop those runs.

So it was a different institutional context, but very much an approach that was entirely consistent I think with Bagehot's recommendations.

Bagehot's name is often mentioned in discussions of the financial crisis, but the idea that what the Fed did during this recent episode is entirely consistent with Bagehot's recommendations may be entirely wrong. As Bernanke points out, Bagehot lived in an entirely different economic environment. In 1873, when Bagehot published Lombard Street (Bagehot, 1873), the Bank of England operated under the Bank Charter Act of 1844 (also know as Peel's Bank Act), which gave the Bank of England a monopoly on the issue of currency in the United Kingdom (except for some grandfathering). The United Kingdom operated under a gold standard, and part of the stock of Bank of England notes had to be backed 100 percent by gold. There was also a fiduciary component to the note issue, not backed by gold, and in practice this was a substantial fraction of the outstanding notes-sometimes a majority.

Banking panics during Bagehot's time were effectively flights from the liabilities of private financial intermediaries to gold and Bank of England notes. Bagehot's recommendation was to stem such panics through unlimited lending to private banks by the Bank of England against good collateral, at a penalty rate. Why the penalty rate? Bagehot appeared to be concerned 
with protecting the gold reserves of the Bank of England and seemed to think the high penalty rate on lending would be an efficient way to limit lending.

But was central bank lending actually an important part of the response to panics that occurred during the 19th century in the United Kingdom? Possibly not. The key problem during these panics was a shortage of media of exchange, so the best response of the Bank of England would have been to put more Bank of England notes into circulation, the stock of gold being essentially fixed (except for international gold flows). During the panics of 1847, 1857, and 1866, which occurred after Peel's Bank Act and before Bagehot published Lombard Street, Parliament acted to suspend the Bank Act, which permitted an expansion in the Bank of England's fiduciary issue of notes. Whether the notes got into circulation through lending or asset purchases by the Bank of England perhaps is irrelevant.

Thus, whether Bagehot's prescriptions were actually an important part of a crisis response during his own time is subject to some doubt. More to the point, it is very hard to say that any important intervention by the Fed during the financial crisis looked much like what Bagehot recommended. For example, a very large lending program was carried out using the Term Auction Facility, under which lending peaked at about $\$ 480$ billion in March 2009. It seems the rationale for this program was the reluctance of financial institutions to borrow due to the stigma associated with standard discount window lending. Under the Term Auction Facility, the Fed chose a quantity of funds to lend, then auctioned this off. That is hardly unlimited lending at a penalty rate.

So, I think it would be useful if we declared a moratorium on the use of Bagehot's name in instances where the name is being used only to lend credence to some contemporary idea. We could probably make a case to do the same for Wicksell, Minsky, and Keynes, for that matter, but that would be taking us too far afield for this article.

It is common, I think, to rate the Fed highly for its performance during the financial crisis. Of course, it is also important to analyze carefully the Fed's behavior in 2007-09 and to be critical, so that we can learn and not repeat mistakes, if there were any. For example, consider the following. An interesting idea is that moral hazard associated with "too big to fail" is not only a long-term problem, but a problem that can present itself in the context of a crisis. For example, the Fed played a very important role in the Bear Stearns collapse. The Fed lent to Bear Stearns just prior to its unwinding in March 2008 and helped engineer its sale to JP Morgan Chase by taking some of Bear Stearns's assets onto the Fed's balance sheet. This Fed intervention, we could argue, then created the expectation among large financial institutions that the Fed was ready to intervene, and this may have led Lehman Brothers to forgo actions that may have circumvented its bankruptcy in September 2008. The Lehman bankruptcy seems to have been critical in precipitating a systemic crisis. So, perhaps the Fed made key errors in the instance of Bear Stearns, which had important consequences later in the year.

Another problem may have been excessive concern by the Fed regarding the solvency of money market mutual funds (MMMFs). These are institutions originally designed to- as much as possible-mimic the functions of commercial banks, without being subject to the same regulations. To the extent that MMMFs borrow short, lend long, and guarantee their creditors a nominal return of zero, they can be subject to the same sorts of instabilities as 
commercial banks. But of course there is no deposit insurance for MMMFs, only the implicit insurance that came into play during the financial crisis, involving both the Fed and the Treasury. But why should the Fed care? MMMFs choose to operate outside of standard banking regulation, and MMMF shareholders should be able to understand the consequences of holding these uninsured shares. And the systemic consequences of a MMMF failure should be slight. Clearly the shareholders lose, but the assets are highly liquid, and it seems easy for another financial institution to step in and pick up the pieces. If we think there is some fire sale phenomenon, that may give the central bank cause to intervene through temporary asset purchases, but why step in to save the MMMFs?

\section{POST-CRISIS POLICY: FORWARD GUIDANCE AND QUANTITATIVE EASING}

For good or ill, there has been a dramatic shift in how central bankers-not only in the Fed System but also in the world-think about policy. The key post-crisis innovation in the United States was (is) an extended period with the short-term policy interest rate at close to zero. This has been combined with the payment of interest on reserves, an increase in the size of the Fed's balance sheet, a dramatic change in the composition of assets on the balance sheet, an increase in the use of forward guidance, and a change in the interpretation of the dual mandate.

The pre-2008 period now seems very strange and simple. As a point of reference, this is the FOMC statement that followed the June 26-27, 2001, FOMC meeting, when Alan Greenspan was Chairman of the Federal Open Market Committee (see Board of Governors, 2001):

The Federal Open Market Committee at its meeting today decided to lower its target for the federal funds rate by 25 basis points to 3-3/4 percent. In a related action, the Board of Governors approved a 25 basis point reduction in the discount rate to 3-1/4 percent. Today's action by the FOMC brings the decline in the target federal funds rate since the beginning of the year to 275 basis points.

The patterns evident in recent months-declining profitability and business capital spending, weak expansion of consumption, and slowing growth abroad-continue to weigh on the economy. The associated easing of pressures on labor and product markets is expected to keep inflation contained.

Although continuing favorable trends bolster long-term prospects for productivity growth and the economy, the Committee continues to believe that against the background of its long-run goals of price stability and sustainable economic growth and of the information currently available, the risks are weighted mainly toward conditions that may generate economic weakness in the foreseeable future.

In taking the discount rate action, the Federal Reserve Board approved requests submitted by the Boards of Directors of the Federal Reserve Banks of Boston, New York, Philadelphia, Atlanta, Chicago, Dallas and San Francisco.

If you have been reading recent FOMC statements, you'll first notice that the above is remarkably short by comparison (202 words vs. 790 in the January 2014 FOMC statement; 
see Board of Governors, 2014). The policy action relates to only one policy variable-the target federal funds rate; there is only a brief description of the state of the economy; there is no attempt to explain why the Fed is taking the action it did-we're left to infer that the state of the economy had something to do with why the federal funds rate target was lowered; there is some vague attempt to address the dual mandate (price stability and sustainable economic growth), but no mention of what economic variables (e.g., PCE inflation rate or unemployment rate) the Fed might be looking at; there is little forecast information, only mention of risks; and there is no forward guidance (i.e., no information about contingent future actions).

In light of the way the Fed now conducts policy, we might think of the above FOMC statement as much less forthcoming than it should have been. But remember that, at the time, people were generally inclined to think highly of the Fed's performance. We may remember quibbles, but there was certainly no consensus that the American public was getting a bad deal from the Fed. But clearly, changes were thought to be necessary during the Bernanke era.

The FOMC has apparently become much more activist. There seems to be a consensus view among FOMC participants_-among whom $\mathrm{PhD}$ economists with high-level research records are increasingly prominent-that the Fed can and should make the world a better place. Alan Greenspan had much more practical background in the private sector compared with Ben Bernanke who, previous to his Fed appointment, had been a high-profile academic researcher at Princeton University. Greenspan's approach was simple: He wanted to control inflation (implicitly, as shown in Figure 1, at about 2 percent per year) and was willing to reduce the federal funds rate in response to low aggregate economic activity. Just how the behavior of the Fed under Bernanke differed from the behavior of the Greenspan Fed will certainly be a subject for study among economic researchers. We might, for example, like to know whether researchers could make inferences about how the Greenspan Fed would have behaved during the financial crisis.

A recent paper (Williams, 2014) does a nice job of showing us the role that formal economics played in post-financial crisis monetary policy in the United States. New Keynesian models were an important influence, of course, and some of the work on such models had already been done pre-financial crisis-for example, by Eggertsson and Woodford (2003), who studied monetary policy at the zero lower bound. A paper by Werning (2012), which came out post-financial crisis, played an important role in post-financial crisis policy discussions, as did Michael Woodford's Jackson Hole Conference paper (Woodford, 2012).

To think about monetary policy at the zero lower bound (on the short-term nominal interest rate), one first has to provide some justification for why it could be optimal for a central bank to choose zero as the overnight interest rate target. In the simplest New Keynesian models (Werning's, for example), that is done by supposing that the representative agent's discount factor is high for some period of time. Then, the real interest rate should optimally be low, but at the zero lower bound the real interest rate is too high, given sticky prices. In this model, then, the central bank would like to ease more at the zero lower bound, but the only game in town is to make promises about future central bank actions. Further, those promises may not be time consistent, so commitment by the central bank is key to making the policy work. 
Bernanke's FOMC got into the business of making promises about the future in a big way. We are now very familiar with the words forward guidance. Initially, forward guidance took the form of "extended period" language, to the effect that the federal funds rate target was to remain low for an extended period of time. As the recovery from the past recession failed to proceed as well as expected, more explicit language was added to the FOMC statement about what "extended period" might mean, first in terms of calendar dates and then as a threshold for the unemployment rate.

In a New Keynesian model, it is clear how forward guidance works. The model will tell us when the central bank should choose a target short-term nominal interest rate of zero, when liftoff (departure from the zero lower bound) should occur, and what the nominal interest rate target should be away from the zero lower bound. All of those things are determined by the path followed by the exogenous shocks that hit the economy. In practice, we do not know how good the model is, we cannot observe the shocks, and even if we believe the model it will not allow us to identify the shocks. So, forward guidance must be specified in some loose way, in terms of something we actually can observe. Ultimately, the FOMC chose the unemployment rate.

What went wrong with forward guidance? If you read Woodford's Jackson Hole paper in 2012, you might understand why we might be in for trouble. Woodford takes close to 100 pages to tell us how forward guidance works, which may be a signal of a potential pitfall of forward guidance policy. People have enough trouble understanding conventional central bank actions, let alone complicated and evolving statements about what may or may not happen in the future. First the Fed committed to the zero lower bound for a couple of years, then for another year. Then it committed to a threshold for the unemployment rate. What does that mean? Is the Fed going to do something when the unemployment rate reaches 6.5 percent? No, not necessarily. It seems there could be an extended period at the zero lower bound. So, ultimately, the FOMC came full circle on this. Current Fed statements about forward guidance specify an extended period, now described as a considerable time after the asset purchase program (QE) ends.

This points out the dangers of commitment, with respect to things that the Fed cannot control. Central banks can indeed control inflation, and the benefits of committing to stable inflation are well understood. One might have thought-pre-financial crisis-that it was also well understood that the central bank's control over real variables-the unemployment rate, for example-is transient. Also, there are so many factors other than monetary policy affecting real economic variables that making promises about real economic activity is extremely dangerous for a central bank. If the FOMC has discovered those ideas again, this is not yet reflected in its policy statements.

Finally, probably the most important novel element in post-financial crisis U.S. monetary policy is QE and the associated increase in the size of the Fed's balance sheet. To understand how the Fed thinks about QE, useful references are Williams (2014) and Chung et al. (2012). Fed officials want to convince us that QE works, and they have tended to downplay the experimental nature of the $\mathrm{QE}$ programs. It has typically been argued by Fed officials that $\mathrm{QE}$ works just like conventional monetary policy (see, for example, Bernanke, 2012). Other than the fact 
that $\mathrm{QE}$ has its effects by reducing long bond yields rather than reducing short rates, the argument is that the transmission mechanism for monetary policy is essentially the same. But what exactly is the science behind QE? This quote from Bernanke (Brookings Institution, 2014) is representative:

Mr. Ahamed: - but we were really operating blind. So in devising QE and all these other unconventional monetary policies, were you pretty confident that the theory would work or that whatever you-going into it?

Mr. Bernanke: Well, the problem with QE is it works in practice, but it doesn't work in theory.

In fact, a model in which QE does not work is the basic Woodford New Keynesian model (see Woodford, 2003). In a Woodford model, the only friction results from sticky prices (and maybe sticky wages). Otherwise, financial markets are complete, and there is nothing that would make particular kinds of asset swaps by the central bank matter. Indeed, baseline New Keynesian models leave the liabilities of the government and the central bank out of the analysis completely. So, in the context of post-financial crisis monetary policy, one modelthe New Keynesian model - is being used to justify forward guidance, but it is going to have to be another model-if there is one-that justifies QE. That could be a problem, as we might like to know how those policy tools work together or not.

Absent a model, the Fed went ahead with QE anyway, supported by some ideas about how financial market segmentation might produce the desired result (Bernanke, 2012). Basically, if the market in Treasury securities is segmented by maturity, or if the market in mortgagebacked securities (MBS) is segmented from the market in Treasuries, then if the Fed purchases long Treasuries or MBS, the prices of these securities will rise and their yields will fall. Then, the argument goes, declines in long bond yields will increase spending in exactly the way that reductions in the federal funds rate target would stimulate spending under conventional conditions.

So, clearly, the Fed's view is that, though the theory might be murky, it is obvious that QE works in practice. But perhaps not. For a summary of the evidence, see Williams (2014). The empirical evidence takes two forms-event studies and time-series studies. Basically, what researchers find is that announcements of $\mathrm{QE}$ and actual $\mathrm{QE}$ purchases are associated with subsequent declines in nominal bond yields and changes in other asset prices. There are two problems with the interpretation of the evidence. The first is that, to confidently measure the effects of a particular policy, we need an explicit theory of how the policy works. Clearly, the relationship between the theory-such as it is-and the measurement is tenuous in this case. Second, it is possible that QE could move asset prices-in exactly the way posited by Fed officials-even if QE is actually irrelevant. To see this, suppose a world where QE is irrelevant and everyone knows it. Then, of course, QE will not make any difference for asset prices-or anything else. But suppose, in the same world, that the central bank thinks that QE works and financial market participants believe the central bank. Then QE will in fact cause asset prices to move as the central bank says they will, at least until everyone learns what is going on. Models like that would be very difficult to work out, but this phenomenon could well be part of what we are dealing with. 
Given that Bernanke and the other members of the FOMC had little idea what QE might actually do in practice, how did they go about determining the magnitude of the interventions? For example, QE2 was planned as $\$ 75$ billion per month in purchases of long-maturity Treasuries over 8 months, and the current program was an open-ended purchase of $\$ 85$ billion per month in long Treasuries and MBS. Obviously, some judgment was made that $\$ 75$ to $\$ 85$ billion per month in purchases was about right. Why? Chung et al. (2012) perhaps give us some clues. The important part of their paper in this respect is section 3, page 66. There is an exercise in which the quantitative effects of QE are measured. The basic idea is to take the Fed's FRB/US model as a starting point. In that model, we can conduct policy experiments such as changing the future path for the federal funds rate to determine how that matters. But, it seems, one cannot conduct experiments in that model to determine how changes in the composition of the Fed's balance sheet matter. Certainly that model will not tell us the difference between long-maturity Treasury securities and MBS. So, what is done is to translate a given quantity of asset purchases into a given change in the federal funds rate by making use of the available empirical evidence and then conducting the experiment as a change in the path for the federal funds rate.

There are two problems with that. First, we may not want to take seriously what the FRB/US model tells us about conventional monetary policy, let alone unconventional policy. What is in the FRB/US model is documented in Tulip (2014). The model is basically a dressed-up version of the types of macroeconometric models that were first built in the 1960s. Indeed, the FRB/US model is descended from the FRB/MIT/Penn model (see Nelson, 1972) - a late1960s-vintage macroeconometric model comprising several hundred equations-basically an expanded IS/LM model. Robert Lucas (1976) and Christopher Sims (1980) were quite convincing when they told us we should not believe the policy experiments that were conducted using such models. My best guess is that there is nothing in the current version of the FRB/US model that would change our minds about the policy relevance of large macroeconometric models.

The second problem with the implementation of QE is that there may be aspects of these programs that work in quite different ways from conventional monetary policy. There is no good reason to think that swapping outside money for T-bills (effectively what happens under conventional conditions) is somehow the same as changing the maturity structure of the outstanding consolidated government debt. Indeed, in Williamson (2014), QE has some very different effects from conventional monetary policy.

Ultimately, though, QE in itself is not a big concern. Either it works or it does not; and, if it does not work, there is no direct harm. There is no good reason to think that QE is inherently inflationary. For example, in Williamson (2014), the long-run effect of QE is to lower inflation. Why? In that model, QE substitutes good collateral for less-good collateral, which relaxes financial constraints and lowers the liquidity premium on safe collateral. Real bond yields rise and, given a fixed short-term nominal interest rate (zero, say), inflation must fall.

As well, the size of the Fed's balance sheet is not a concern. For example, if the Fed expanded its balance sheet by issuing interest-bearing reserves to purchase T-bills, we should not be worried. If the Fed's balance sheet is expanded by purchasing long-maturity Treasury bonds, 
we should also not be worried, provided there are no unknown effects of changing the maturity structure of the Fed's assets. Finally, even though the Fed is now borrowing short and lending long, in a massive way, we should not care if, in the future, the Fed starts earning negative profits. Economically, that does not matter. In essence, what matters is the consolidated balance sheet of the Fed and the U.S. Treasury, and it is irrelevant whether the Fed pays the private sector interest on reserves or the U.S. Treasury pays the private sector interest on government debt.

\section{CONCLUSION}

So what should we make of the state of monetary policy in the United States as Ben Bernanke leaves the Fed? Primarily, I think, the Fed is unsettled about what it should be doing, and the public is uncertain about what it should be expecting from the Fed. It is fine to experiment, and everyone understands that the human race would get nowhere without experimentation. But when the Fed experiments, it needs to cast a critical eye on those experiments. I think it is unclear whether forward guidance has been of any value, and it is possible that careful a priori thinking could have headed off that experiment.

With QE, I think much theoretical and empirical work needs to be done to clarify the role of such policies. Whether QE has quantitatively significant effects or not, a key question is whether it is appropriate for the central bank to be engaging in debt management, which has traditionally been the province of the fiscal authority. Indeed, while QE was taking place, with the Fed acting to reduce the duration of the outstanding consolidated government debt, the Treasury was sometimes taking actions that would have the effect of increasing the average duration of government debt in the hands of the public. Given the view on the FOMC that QE works as advertised, it seems likely that QE will be put away, in the box of good monetary policy tools, for later use. If the maturity structure of the outstanding consolidated government debt is so important, then there should be a public discussion of who is to determine it - the Fed or the Treasury.

Finally, perhaps the most important lasting change in policy that comes out of the Bernanke era is a greater tendency of the Fed to focus on short-run goals rather than long-run goals. Indeed, the Fed's concern with the state of the labor market, as reflected in recent public statements by Fed officials, may have evolved into a belief that the Fed can have long-run effects on labor force participation and the employment/population ratio. That belief appears to be unsupported by theory or empirical evidence. Further, it is possible that two or three more years with the Fed's policy interest rate close to the zero lower bound will not help to fix whatever ails the labor market, nor will it increase the inflation rate, as low nominal interest rates (for example, as in Japan since the early 1990s) typically lead to low inflation in the long term (see Bullard, 2010). If the Fed falls well short of its 2 percent inflation goal for some period of time, it is not obvious that would be so harmful, but at the minimum it harms the Fed's credibility. 


\section{REFERENCES}

Bagehot, Walter. Lombard Street: A Description of the Money Market. London: H.S. King, 1873.

Bernanke, Ben S. “Inflation Targeting." Federal Reserve Bank of St. Louis Review, July/August 2004, 84(4), pp. 165-68; http://research.stlouisfed.org/publications/review/04/07/PanelDisc.pdf.

Bernanke, Ben S. "Monetary Policy Since the Onset of the Crisis." Presented at the Federal Reserve Bank of Kansas City Economic Symposium, "The Changing Policy Landscape," Jackson Hole, Wyoming, August 31, 2012; http://www.federalreserve.gov/newsevents/speech/bernanke20120831a.pdf.

Board of Governors of the Federal Reserve System press release, June 27, 2001; http://www.federalreserve.gov/boarddocs/press/general/2001/20010627/.

Board of Governors of the Federal Reserve System press release, January 25, 2012; http://www.federalreserve.gov/newsevents/press/monetary/20120125c.htm.

Board of Governors of the Federal Reserve System press release, January 29, 2014; http://www.federalreserve.gov/newsevents/press/monetary/20140129a.htm.

Brookings Institution. "Central Banking After the Great Recession: Lessons Learned and Challenges Ahead: A Discussion with Federal Reserve Chairman Ben Bernanke on the Fed's 100th Anniversary." January 16, 2014; http://www.brookings.edu/events/2014/01/16-central-banking-after-the-great-recession-bernanke.

Bullard, James. "Seven Faces of 'the Peril'." Federal Reserve Bank of St. Louis Review, September/October 2010, 92(5), pp. 339-52; http://research.stlouisfed.org/publications/review/10/09/Bullard.pdf.

Chung, Hess; Laforte, Jean-Philippe; Reifschneider, David and Williams, John C. "Have We Underestimated the Likelihood and Severity of Zero Lower Bound Events?" Journal of Money, Credit, and Banking, February 2012, 44(Suppl. s1), pp. 47-82.

Eggertsson, Gauti B. and Woodford, Michael. "The Zero Bound on Interest Rates and Optimal Monetary Policy." Brookings Papers on Economic Activity, 2003, 34(1), pp. 139-211.

Lucas, Robert E. Jr. “Econometric Policy Evaluation: A Critique." Carnegie-Rochester Conference Series on Public Policy, January 1976, 1(1), pp. 19-46.

Nelson, Charles R. "The Prediction Performance of the FRB-MIT-PENN Model of the U.S. Economy." American Economic Review, December 1972, 62(5), pp. 902-17.

Sims, Christopher A. "Macroeconomics and Reality." Econometrica, January 1980, 48(1), pp. 1-48.

Tulip, Peter. “FRB/US Equation Documentation.” May 2014; http://www.petertulip.com/FRBUS_equation_documentation.pdf.

Werning, Iván. "Managing a Liquidity Trap: Monetary and Fiscal Policy." Working paper, MIT, April 2012; http://dl.dropboxusercontent.com/u/125966/zero_bound_2011.pdf.

Williams, John C. "Monetary Policy at the Zero Lower Bound: Putting Theory Into Practice." Hutchins Center on Fiscal and Monetary Policy, Brookings Institution, January 16, 2014; http://www.brookings.edu/ /media/research/files/papers/2014/01/16\%20monetary\%20policy\%20zero\%20lower \%20bound/16\%20monetary\%20policy\%20zero\%20lower\%20bound\%20williams.

Williamson, Stephen D. "Scarce Collateral, the Term Premium, and Quantitative Easing." Working Paper No. 2014008A, Federal Reserve Bank of St. Louis, March 2014; http://research.stlouisfed.org/wp/2014/2014-008.pdf.

Woodford, Michael. Interest and Prices: Foundations of a Theory of Monetary Policy. Princeton, NJ: Princeton University Press, 2003.

Woodford, Michael. "Methods of Policy Accommodation at the Interest-Rate Lower Bound." Working paper, Columbia University, September 16, 2012; http://www.columbia.edu/ mw2230/JHole2012final.pdf. 
